\title{
Linguistic Contexts and Contacts in Infantile Discourse
}

\author{
Kledi Satka (Shegani), (Doç.) Dr. \\ Lecturer University of Tirana, Faculty of History and Philology, Linguistics Department \\ Email.kshegani@yahoo.com

\section{Lindita Xhanari (Latifi), Assistant Professor} \\ Lecturer, University of Tirana, Faculty of History and Philology, Linguistics Department \\ Email.lindalatifi@yahoo.com
}

\section{Doi:10.5901/ajis.2015.v4n1s1p97}

\section{Abstract}

Nowadays when multilingualism seems to be a very tangible reality in our environment it is of interest to study some linguistic elements, which enable the analysis of the linguistic awareness of the speaker in language set. This analysis should in fact be realized in certain contexts that can easily summarize the study: family contexts, school and society, also by analogy with Fishman hypothesis regarding early bilingualism, whereby three are the areas in which this phenomenon should be studied: family, peers (peer group) and schools. Our paper will bring data regarding the acceleration of the psychological development of tender age , 0-3 years even under the influence of mass media such as radio TV, DVD, that being for hours in the eyes and ears of the juveniles facilitate the introduction of words and terms that until recently were regarded as "property "of adults. We note two indicators of this new linguistic reality of the language acquisition from the child in the new social and linguistic context. First; acceleration of capturing elements of written language in a real visual aspect that appears today, since the age of two years. We take in the account the delivery of some children, not as exception, but as a product of the experiences of today's new orientation in the civic onomastic our country. A more significant example is that of children who differ: QTU, EHV, KMY, etc., still without any idea what these letters represent itself etc. Second; situation almost multilingual of modern Albania, especially in Tirana and major centers and the addition of mixed marriages with foreigners and Albanians. Linguistic context actually is the determinant of coordinates of the contacts that the child sets as a speaker that have embezzled more than a linguistic system. Context sets the type of linguistic contacts. The bilingual child in certain language contexts selects the discourse code, depending on the interlocutor and the situation. Usually the words chosen to implement such communication in bilingual contexts constitute what we might call "emergency language"; the kind of language that fits the context of the speaker to realize the only intention, communicating.

Keywords: Linguistic Contexts, Contacts in Infantile Discourse

\section{Social Context and Language Contacts}

In the study of language, children's speech is an area which should be the first station where scientific thought should stop. Often we forget the basics of the language we receive in our early childhood, at the time when we are still unaware of the importance of language in social life. From the first moments of life, the child is an open system that is organized, managed and gradually involved in the development of its natural and human environment. Studies of children and language are multilateral; it is the lecture, or the spoken language, that is the mirror of reality with which the child comes in contact since the first days of life.

According to Bruner, intellectual development is influenced by the way in which human beings gradually learn to present the world through action, image and symbol. ${ }^{1}$

In today's environment, when multilingualism appears to be a very tangible reality. It is of interest to study some linguistic elements, which enable the analysis of linguistic awareness of the speaker within the linguistic community. In fact, this analysis should be realized in certain contexts that can be summarized to facilitate the study in: family, school and social life contexts. Regarding early bilingualism, the analogy with the Fishman hypothesis states that there are areas

${ }^{1}$ Bruner, J., (2000), La cultura dell'educazione, nuovi orisonti per la scuola, Fetrineli Editore 
which should be studied within this phenomenon: family, peers (peer group) and schools.$^{2}$ These are the contexts in which a man establishes contact, not only linguistic, with himself and with others. Language contacts are like "a kaleidoscope influx of impressions to be organized largely by the linguistic system of our minds." 3

It is very interesting to study a different view, that of the binomial, language-child, in the light of new coordinates in which our society has shifted with the overwhelming influence of television and other sources of global information to which children fall into contact in their developmental years. Conformity and individualism are two sides of the same coin that the child accredit to the surrounding environment trying to get from it as much as possible.

\section{The Child Speaks and Understands Both Languages}

When talking about multilingualism and in particular for the acquisition of two languages in early childhood, one thing can be said with certainty: the child raised in a bilingual environment (biling) can understand and speak both languages simultaneously. This conclusion belongs to the spoken language, as with the written language is not quite the same thing. Usually, the process of literacy begins later, moreover after 6 years of age, but occurs only in one of the languages and usually in the language in which the child goes to school and then in the second language.

The child located in a bilingual environment has learned two languages, which represent two different systems. But is clearly proven by numerous studies that "children from a very early age adjust their lecture to their social context. ${ }^{4}$

Social contexts play the role of linguistic variables in the bilingual system of communication. Thus, if a child living in Italy possesses the Italian language as an official language should shift to another social context, in Tirana for example, there will be a different result. This of course will be obtained in communication and will be reflected in the discourse. The child begins to set in motion an active fund of Italian words and a passive fund Albanian words to structure its thinking, and begins to communicate in Albanian, or Albanian and Italian, according to the situation and interlocutors. So, in this case, it is the linguistic context that gives its effects on teaching. "An individual may be associated with many distinct networks each predictable by their linguistic norms."

In the ages 5-6 years old, children begin to reshape the linguistic rate offered by their parents within the peer group. It can be said that a bilingual child builds a multidimensional model of his language by knowing in what situation to use one language and in what to use the other one. Having conversed with other children, playing with them, the child follows the linguistic rules of the community where it belongs. In the transition from home to school, the language of the family from the one at school makes the relationship between language and social context change completely.

The best part of communicative situations in the context of family and various game events are characterized by practical functions, unplanned language models, and spontaneity. The school is a structured linguistic environment, with multidimensional functions and conducted under the direction of the teacher.

School has a strong impact on children's linguistic formation, because it creates a new context, wherein new uses of language are developed. Each student is, in fact, the co-author of its formative process and school plays the role of catalyst of the linguistic influences on the communicative competence and of early bilingualism. This is obviously being conditioned from socio-cultural variables, which, no doubt with their value, they influence the formatting of the child's ability to know and speak both languages.

\section{Bilingual Concrete Situations in the Social Albanian Context}

For the majority of the Albanian children living abroad with Albanian parents (where their families speak mainly English) they experience the acquisition phase of the new conversation code (the language of the country where they live) in the early stages where they alternate between the two languages. This is due to the lack of linguistic competence suitable for every context. "The purpose of mixing of codes, apparently symbolizes a somewhat ambiguous situation in which any language used alone will not be sufficient."

Children create needed experiences of communication to express their needs and desires. This gives them the

\footnotetext{
2 Fishman, J., (1965) Who speaks, what language, to whom and when, "La linguistique"2.

3 Whorf, B., (1940) "Science and Linguistics" Technological Review 42 229-311

${ }^{4}$ Andersen, E. (1990) Speaking with stlyle. The sociolinguistic skills of children,London Routledge.

${ }^{5}$ Hudson, R,(2002) Sociolinguistika, Botime :"Dituria" faqe 202.

${ }^{6}$ Hudson, R,(2002) Sociolinguistica, Botime :"Dituria" faqe 65.
} 
motivation and the opportunity to discover the organization of the formal systems of linguistic stocks from the imitation of the adult speech to the realization of intentional communication in both languages, according to certain contexts. In one case, a 2-year-old girl who was born and raised in Italy, but who spoke Albanian, was obviously influenced by her mother tongue and family environment. But at the time that she went to kindergarten she was influenced by the language spoken there, although she understood Albanian very well, school had begun "to destroy" from her active vocabulary the Albanian words. But those words "reawaken" only when she comes into contact with people who speak Albanian.7

From the examples observed during our work, we noticed that the child in a bilingual environment, eg: ItalianAlbanian knows how to adapt and respond "by country, the assembly". So, when she is talking with the Italian mother she responds in Italian, and when talking with the Albanian father, she speaks Albanian. This kind of communication extends even further with the grandparents and other relatives, even in kindergarten with peers and teachers. So, we are dealing with her mastery of both codes of discourse, of which she has been affected since birth and is being served from them according to the situations.

Let us mention the case of a child who lived in Athens, Greece. He had been living there for 4 years. He had visited Albania several times over those years, where he stayed 7-10 days and sometimes more than one month. He was born in Athens and until the age of two, he had stayed at home alone with his mother. His mother said that they spoke Albanian while at home, but during the gathering with friends who lived and Greece, the Greek language was spoken as well. Thus, the child learned a few words of Greek language even though often not accurately spoken. He began using the words: ela- come; psomi-bread (when he wanted to eat). After two and a half years of age, he went to kindergarten. There, an immediate change of his speech became apparent. His speech was enriched more and more with Greek words. From then on, the child would hear the Albanian language only at home.

During his visits in Albania the child learned Albanian words. But the stock of his words contain more Greek than Albanian words. But in Albania, he would say words like: agac-thug; leka-money, eze-aunt or even mix of codes such as "ikim valta" (lets go for a walk) or "ksilo mami (mom will beat you), etc. Even the Greek word "oqi", he would say it as "eqi". When he would come to Albania, people would spoil him and would speak to him with incomplete words, removing some letters. Under the influence of this situation, the child redesigned language saying AJA for the uncle, una for me, i logel for small, etc. Over time, he began to better articulate the words in Albanian, but only when he came to Albania. In Athens he was influenced by the language of the kindergarten and spoke only Greek although he understood the Albanian language quite well.

Children with Albanian parents living in the English-speaking community that come in Tirana, according to case studies, observe the fact of using the genitive case. "I like Leksa's stuff," said the 6-year-old child E.A, admiring her dolls and toys. The sentence is a mixture of Albanian-English codes and in the terms of genitive case it is noticed that the children find it easier to use the English language form. We have encountered this phenomenon in many case studies. Specifically here are some examples: I love Era's Barbie, I need Alku's book, I want a ball like Henry's.

They select the "characters" with whom they speak English and those with whom they speak Albanian. With the parents they speak English in Tirana, although in Toronto, they speak Albanian with them. While with others who live in Albania, they speak and communicate in Albanian, or with a mixture of Albanian-English codes.

The choice of English-speaking parents to speak Albanian while in Tirana, and to speak English while in Toronto is a phenomenon that presents a great deal of interest from sociolinguistic perspective. To establish communication, the child chooses the code of the discourse and the interlocutors relying on the context without the need for the grammar rules of the language. One element to be highlighted is the acceleration of capturing the written elements of the language in a real visual aspect that appears today, since the age of two years. We consider the deliveries of some children, not as an exception, but as a product of the today's experiences of the orientation in the new civic onomastic and of our country. A very significant example of this is that of children who differ: TEG, EHV, KMY etc., without even any idea what these characters represent in themselves.

The fund of passive vocabulary in the Albanian language appears to such proportions that allows the child to understand and speak good English with a mixture of linguistic codes. Such sentences as: I miss my mami, I want buke, I want akullore, I like to go ne plazh, I'm listening to muzike shqiptare, are clear evidence that the child empowers the entire bilingual arsenal to communicate his message, and to do so in a broad multi-lingual manner. These sentences are constructed in such a way that, although they don't obey grammatical rules, they are understood by the interlocutor. So

${ }^{7}$ Satka,K. Gjuha e fëmijëve përballë informacionit global, Seminari XXVII Ndërkombëtar për Gjuhën,Letërsinë dhe Kulturën Shqiptare, faqe 304. 
the child chooses and selects the interlocutors and situations to use its taught linguistic knowledge. In such a case we are able to anticipate that by adjusting the grammar, this person can move easily within two linguistic systems and pass from one to another depending on the situation. This theoretical explanation applies closely to a bilingual speaker facing two language systems, with syntactic constructions and lexical elements that intertwine and sometimes are used separately, according to their respective linguistic system.

To achieve the correct effect, speakers "balance two languages with one another in a sort of linguistic cocktail, a few words from one language, then some few words from the other language, then back to the first language with a few more words, and so on. Generally switching from one language to another occurs more or less at random, according to the topic of the conversation." 8

\section{Summary}

In conclusion, it can be said that it not merely the linguistics but the the context and the contacts which are important elements that determine aspects of language behavior associated with the discourse of social behavior. It is the context that decides the sets of linguistic contacts. The bilingual child in certain linguistic contexts may select the conversational code depending on the interlocutor and the situation.

At different levels of language, the thing that kids do easily is to understand others is bilingual lexical selection, which is set in motion in mixed syntactic constructions according to linguistic models of one or another language. Usually, the words chosen to establish communication in such bilingual contexts constitute what we might call "emergency language".

This is a kind of language, which fits the context of the speaker to realize the only goal: communication. This language somehow avoids linguistic norms of the two systems and makes an adjustment with the context that realizes the communication. This means that to communicate, the child uses its own conceptual and linguistic "grammar" according to certain social contexts. "Recent pedagogical, psychological and linguistic studies have shown that the child has a greater capacity to build empirically, through relationships with members of its community, a bi-verbal or multivalve skill, thanks to which it gains a mastery of two - or multiple linguistic systems. ${ }^{9}$

Faced with this spectrum of systems, sociolinguistic value is transmitted through communication being shifted from one social context to another with tools and more diverse ways; direct contacts, mental images, games, chats, imagination, media outlets etc. Bilingual language contacts are indicative of stages through which passes the altered conversational codes in a consciousness language of the speaker until the total completion of linguistic formation as the highest degree of the possession of two linguistic systems.

The language of children should be considered as the foundation of formatting a human personality which runs from stuttering and baby-talk, to imagination, and ultimately to processed logical thinking. In recent times, everywhere in the world, and now also in the Albanian environments, as a result of increased incentives of the "electronic discourse" (games with sounds, words, sounds, music, etc.,) "as well as cartoons that are provided by television channels with videotapes or DVDs, we can observe an acceleration of the overall development of mental and linguistic in children.

\section{References}

Austin, J., Language Differentiation and the Development of Morphosyntax in Bilingual Children Acquiring Basque and Spanish, Ithaca, NY:Corneil University, 2001.

Buzan, T., Truri i fëmijës, Botimet "Max", 2006.

Fishman J., (1965) Who speaks, what language, to whom and when, "La linguistique"2.

Whorf, B. (1940 "Science and Linguistics" Technological Review 42.

Andersen, E. 1990 Speking with stlyle. The sociolinguistic skills of children,London Routledge.

Hudson, R.,(2002) Sociolinguistica, Botime :"Dituria".

Koutsouvanov, E.,(1993) Television and child language development, International Journal of Early Childhood 25 f.27-32.

Shkurtaj, Gj., 2003 Sociolinguistika, SHBLU ,Tiranë.

Shkurtaj Gj., Etnografi e të folurit të shqipes, SHBLU, Tiranë, 2004.

Tabors,P., One child, two languages.A guide for educators of children learning english as a second language, Baltimore Paul H.Brookes. Trudgill, P., Sociolinguistics: An Introduction to Language and Society, Penguin Group, Fourth Edition, 2000.

${ }^{8}$ Hudson, R., (2002) Sociolinguistica, Botime :"Dituria" faqe 65.

9 Shkurtaj, Gj., 2003 Sociolinguistika, SHBLU ,Tiranë,faqe 179. 